\title{
Importance of Intellectual Capital and Business Education as Global Topic in Development of Company International Business from the Perspective of Company Management
}

\author{
Lech Nierostek $^{1, *}$, and Petra Horváthová ${ }^{1}$ \\ ${ }^{1}$ VSB-Technical University of Ostrava, Faculty of Economics, Department of Management, Sokolska \\ trida 33, 70200 Ostrava, Czech Republic
}

\begin{abstract}
.
Research background: The company intellectual capital is increasingly becoming a global topic. Modern countries building their development on knowledge are aware that intellectual capital, and therefore human capital, can become and becomes global capital not only in international companies. It will be also crucial for the concept Industry 4.0.

Purpose of the article: The aim is to find out how the company management approaches the skills and knowledge of its employees thus the intellectual capital, which is becoming a global topic and contributes to the company international business development.

Methods: The methodology begins with defining a research problem. Research questions are formulated, a questionnaire is created, the basic sample of respondents is identified and a pilot study and a semi-structured interview verifying some of the questionnaire questions are conducted. Subsequently, a questionnaire survey is realized. The data obtained are filled in the Excel software and the results are presented by figures and verbal description. By answering the research questions, the methodology is fulfilled.

Findings \& Value added: The research revealed a great discrepancy between the assumed and declared state in the field of work with intellectual capital and employee's education. It shows the weaknesses being relevant to our country as well as abroad. The results show random employees training, minimal identification of employees' potential, low importance of services and products quality as well as insufficient interest in turning tacit knowledge into explicit, etc. Research conclusions and recommendations will become very actual even in the period after COVID19.
\end{abstract}

Keywords: Intellectual Capital; Human Capital; Company Management; Discrepancy; Questionnaire Survey

JEL Classification: $M 12$; $M 53$; $M 29$

\footnotetext{
*Corresponding author: lech.nierostek@,vsb.cz
} 


\section{Introduction}

The world around us is changing, evolving and sometimes so rapidly that we begin to perceive chaos as a new norm, part of the reality surrounding us. A change is brought by leaders or unforeseen circumstances. Examples include the successful flight of SpaceX or the global pandemic Covid-19. Changes are a natural part of organizations' and businesses' lives. Being a passive recipient of the change is indeed possible or there is an option to predict change and bring it to life, not to be surprised.

How to do it? On what to build the company's success and its future, for example in the concept of Industry 4.0.? It is worth mentioning that Industry 4.0 requires businesses to transform themselves by replacing the old technologies, processes, and interactions with new ones. Further, in the presence of staggering effects of COVID-19, the need to transform businesses according to the paradigm of Industry 4.0 is ever-increasing as the firms not only have to maintain a balance between their innovation and market exploitation activities but also need to enhance their technological absorption capacity (TAC) to cope with the challenges posed by the this pandemic [1]. How to succeed in the regional as well as the global market? The answer is hidden in the intangible value, the company's assets.

What are they? The resources and competencies that are for competitors most difficult to imitate are those I can rely on: innovation, or the ability to introduce new products and services on a regular basis, flexibility or the ability to implement changes in response to market changes, loyal, determined and well-trained employees and leaders who can inspire them, a strong brand (today as important as before), an excellent reputation (more important today than ever) as well as IT, production and service systems that can provide customers with exactly what they want when they want to keep problems and delays to a minimum [2].

A success of the countries and organizations with the greatest influence is based on their knowledge. They use this knowledge to the maximum extent and, thanks to their skills, further develop them. In the knowledge-based economy, knowledge is considered a strategic resource that helps entities to become market leaders. For years, this strategy has been used successfully by companies operating in various economic sectors [3]. Quality service or product is a matter of course expected today. An intangible benefit is considered the added value for the customer, something extra, such as approach to the customer, a positive impact on the environment, unexpected service or additional functions differing from others. In the era of the knowledge-based economy, knowledge is, on the one hand, input as a production source and, on the other hand, it brings output in the form of intellectual product [4]. All this is not possible without a high level of the above-mentioned intangible capital, which includes intellectual capital, consisting of human capital, organizational capital and customer capital.

Intellectual capital is the organized knowledge being possessed by organization, which this organization practices and uses and which serves to create wealth. [5]. The human capital is the cornerstone of intellectual capital. The motto "human capital" hides all the skills, knowledge and experience of employees and managers of the company. However, it has to be more than the sum of these measures, it also has to include the dynamics of a smart organization in a changing competitive environment. [6].

Development of knowledge, skills and abilities as well as working with the dynamics of the organization or making it more energetic is inextricably bound to corporate education. Therefore, it is necessary to search for and analyze all the connections between intellectual capital, corporate education and business development. 


\section{Literature review}

Much has been written about the importance and necessity of a managerial approach of the management to knowledge, skills and abilities of employees, therefore intellectual capital of the company, which is becoming a global topic and contributes to the development of international business. In this context, it is emphasized how difficult it is to change thinking and especially in the area of intangible values, intellectual capital. Most companies reluctantly accept all changes in the way of management. There are pressures associated with daily operation. Many people are unwilling to even think that some things can be done differently. Intangible assets in particular can be perceived with skepticism [2].

It is being difficult to persuade the company management to consider the intellectual capital the source of company development, competitive advantage. What is company power and wealth about? The value of Intel or Microsoft does not lie in bricks or mortar, not even in inventory but in other, intangible assets - intellectual capital [6].

Education in relation with knowledge, skills and abilities is important. Knowledge is the advantage, learning is a necessity - it has always been acknowledged but starting with knowledge-based society those characteristics are becoming the fundamental competitive advantage and the basis to create the wealth [7]. For company's development, connection of all parts of intellectual capital has been proved important. We therefore propose human and structural capital to be an anchor of absorption capacity with a subsequent strengthening role in the success of Open Innovation [8].

What seems obvious at first sight needs to be quantified, although it may seem difficult. Profit has to be able to be measured in everything that contains intellectual capital. If intellectual capital is to be attributed value, it has to be expressed in monetary units (or in another, as yet undetermined substitute). Development of a new technology and its transformation into a real product can last months and years but in a particular moment, it has to be transformed into the company profit. In the same way, higher satisfaction of customers, employees moral and other factors have to be reflected in higher revenues, lower overhead costs or higher profits or vice versa [6].

The study provided in Great Britain in 2019 has found out that if employees are educated and number of the trained is increased by $1 \%$, the productivity increases by $6 \%$ [9]. Another study, mentioned by Konings and Vanormelingen, brings the conclusion that productivity of educated employee compared to uneducated one is higher by $23 \%$ [10].

Intellectual capital is said latent advantage, which the company is aware of; this intellectual capital is further cultivated and thus develops and creates developing and selflearning company, in which information transfer becomes natural part of company's life. Profitability through a growth - in pursuit of takings increase means that companies have to be creative and innovative and thus support and encourage employees to transfer information, knowledge and experience freely among themselves (mutual learning) [11]. All this forms and at the same time is part of a high corporate cultura. The culture of an organization is the basis for knowledge transfer that can develop an informal learning process without the intention of teaching [12].

Literature dedicated to the intellectual capital mentions problems of the management to accept a change, a new paradigm. It shows contributions related to implementation of intellectual capital, teaches how to assess it, points out the most contributive areas. Besides the intellectual capital and organizational performance, interest in relation between knowledge management and intellectual capital as well as knowledge management and organizational performance is growing [13]. The world is speeding. There is Industry 4.0, which allows to create a completely new direction of research of competition between human and artificial intellectual capital in production and distribution in Industry 4.0, in 
which the optimization of social consequences is not achieved by limiting automation, but by stimulating it [14]. However, no one deals in more detail with the management's approach to the knowledge, skills and abilities of employees, thus to what level they know the intellectual capital topic. That is the reason why the research has been focused on just this area, more specifically on Czech companies with the size up to 500 employees.

\section{Methods and data}

In their aims, theses related to intellectual capital, corporate education and business development do not deal with interrelations of individual areas. They do not examine knowledge of management related to the above-mentioned including attitudes they take towards them.

Based on those findings, the authors formulated the research problem as follows: what is the relation between the intellectual capital, corporate education and business development. They also were interested in how the company management approaches knowledge, skills and abilities of employees thus company intellectual capital.

In the frame of the research, the following questions were asked:

1. Does the idea (principles) of intellectual capital affect the level of internal education?

2. Does the company intellectual capital influence the development of its business?

3. Does most management consider the level of corporate education an organized approach?

For this purpose specially designed questionnaire became the tool to answer research questions containing 43 questions detailing the given topic. While designing the questionnaire, the authors considered experience of production and academic environment. The fundamental knowledge of the production environment enabled the creation of verification questions, which would proved or disproved the above-mentioned research questions.

The prime sample of 410 respondents was created by random choice method out of the basic set involving owners, shareholders, TOP management members, HR department members or another department member, task of which the co-responsibility for recruiting new employees is, managers (participating in the selection of their subordinates) of companies with up to 500 employees throughout the Czech Republic. Those people were addressed by a personal e-mail explaining the aim of the questionnaire survey, request to fulfill the questionnaire within given period of time as well as acknowledgement to all for time devoted to it. Prior to the research, a pilot study (10 employees of the abovementioned posts) had been carried out to verify the comprehensibility of the questions. As it comes to the questionnaire survey itself, 143 questionnaires were returned, i.e. $35 \%$. As for correctly fulfilled questionnaires, 100 were properly fulfilled making thus the final sample of respondents of 100 (return rate of the prime sample is $24 \%$ ).

The questionnaire survey (data collection) began in February 2018 and was finished in April 2018.

In the following months, data collection took place using the method of questioning, the technique of semi-structured interviews, in which 14 respondents participated $(100 \%)$. The last interview was finished in March 2019. The aim of the semi-structured interviews was to gain a broader view on the topic and, at the same time, use them as a verification tool for some of the questions in the questionnaire. In total, data of 114 respondents were worked with (100 questionnaire surveys, 14 semi-structured interviews).

The processing of the data obtained from the questionnaire survey was performed using Excel software, where the results were presented by figures and verbal description. The 
results of semi-structured interviews were processed using Excel and Word software and presented in the form of tables, figures and verbal description.

The last step of the research was to answer the research questions. The answers to them are dealt with in the next chapter.

\section{Results and discussion}

Findings of the research show the true status of affairs concerning intellectual capital, corporate education, approach towards employees, etc. to companies of the Czech Republic employing up to 500 employees.

By way of introduction, it has to be said that the evaluation of respondents' knowledge regarding the individual terms related to intellectual capital was also the part of the research. These questions were open and one's own or already described definition was expected. It has to be said openly that the answers showed a superficial knowledge or rather only an awareness of individual terms. This superficial knowledge then reflects assessments not taking part in the research questions; however, the authors mention them in this paper.

The first out of research questions was: Does the idea (principles) of intellectual capital affect the level of internal education? Convincing answer, yes $=82 \%$ of respondents in the frame of questionnaire survey, the Figure 1. offers. As for semistructured interview, positive evaluation was represented by $71 \%$ of respondents. Knowledge of the philosophy of intellectual capital creates more pressure on the level and proper use of internal education. Both of these connected vessels then influence the development of business.

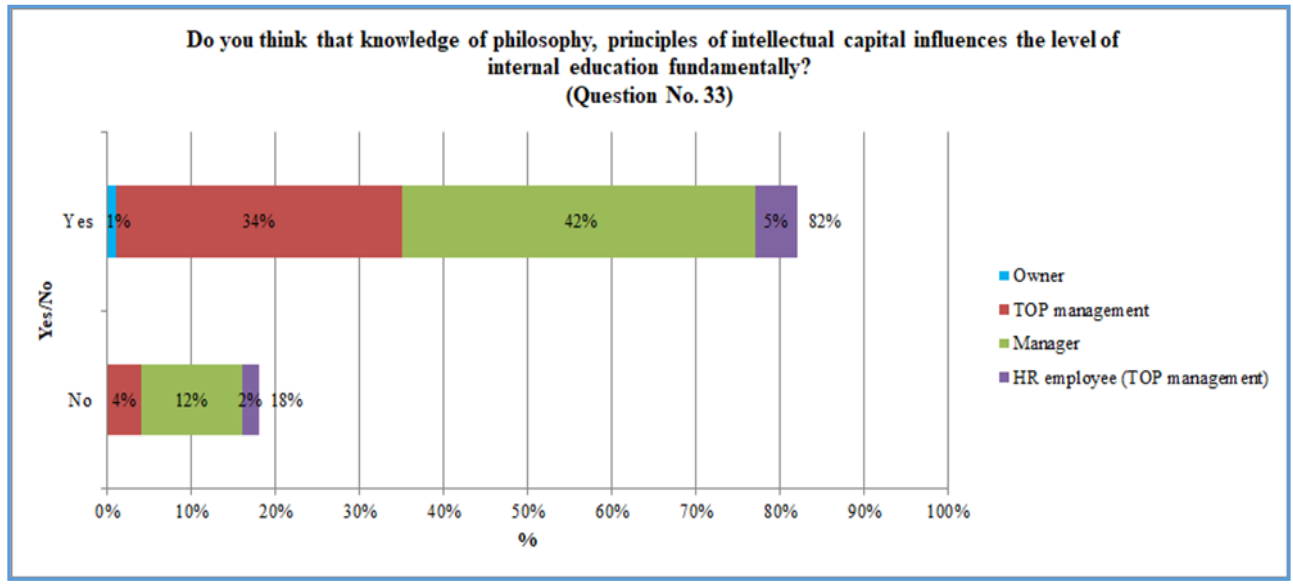

Figure 1. Do you think that knowledge of philosophy, principles of intellectual capital influences the level of internal education fundamentally?

Source: own research (February - April 2018)

The second out of research questions was: Does the company intellectual capital influence the development of its business?

In the questionnaire survey, $86 \%$ of respondents chose rather maximum or maximum level considering the sum of the scale evaluation 5 to 7 , see Figure 2. For a semi-structured interview, all 14 respondents were in the scale range 5 to 7 . The achieved result shows that the majority of respondents - managers are convinced of the fundamental impact of intellectual capital on business development.

The answer to the following question can be count among positive research outputs: Does manager conduct education of his subordinates? Declared answer of $75 \%$ of respondents was yes. 


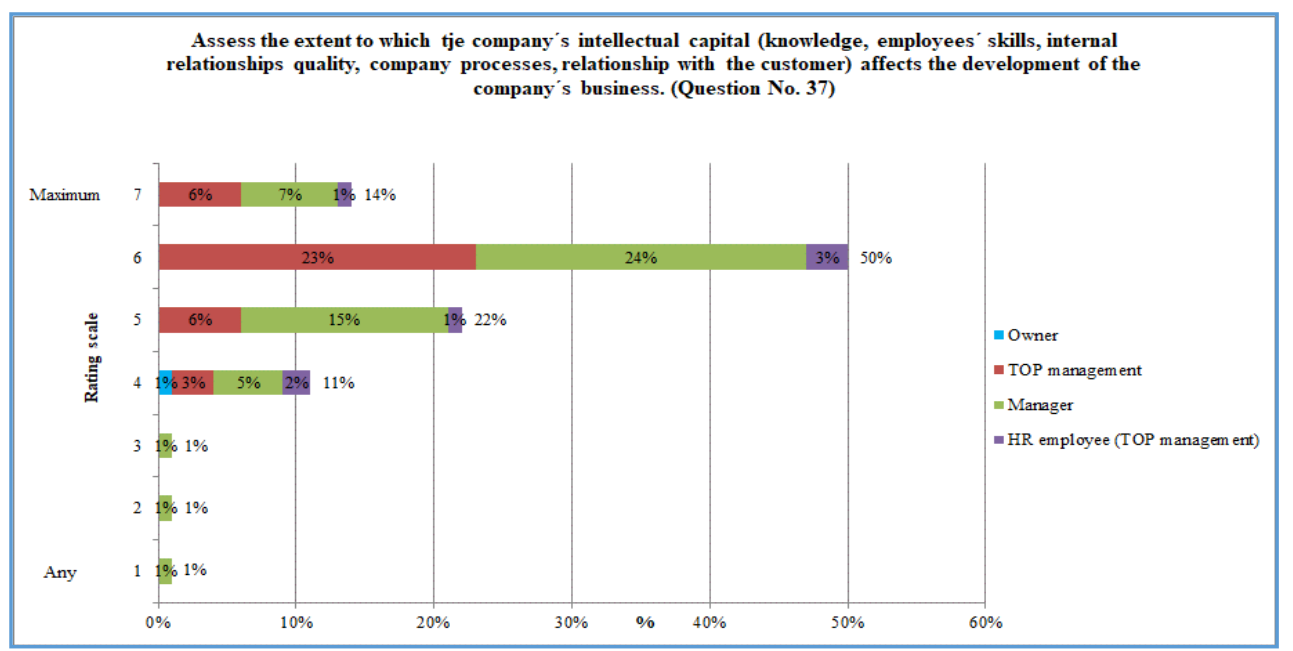

Figure 2. Assess the extent to which the company's intellectual capital (knowledge, employees' skills, internal relationships quality, company processes, relationship with the customer) affects the development of the company's business.

Source: own research (February - April 2018)

The research outputs of the following questions of the questionnaire are more or less in contradiction with above-mentioned.

- How you assess the level of employees' education (development of their potential, knowledge and skills) by their direct superiors? The sum of the scale evaluation 5 to 7 representing the highest level was represented by only $22 \%$ of respondents.

- Determine the degree of evaluation of the corporate education benefits. Ratings ranging from $0 \%$ to $50 \%$ were reported by $89 \%$ of respondents.

- Is there a document in your company that mentions the role of employees (their importance) for the operation, development of the company? The answer not was given by $75 \%$ of respondents.

- To what extent do you measure, identify the potential of employees (knowledge, skills, prerequisites) during their employment in the company? $70 \%$ of respondents stated a range between $0 \%$ and $25 \%$.

Based on these but also other questions mentioned in the questionnaire, it can be concluded that there is a discrepancy between the declared situation and reality.

The third question was: Does most management consider the level of corporate education an organized approach?

The answer to this question can be found in the Figure 3. showing that most respondents assess education in their companies at the level of random access. This finding is dismal.

Interesting result proving a discrepancy between first two mentioned research questions and third one (which is proven) shows the answer to the question: At present time, your company emphasizes the most: quality, volume, costs, virtual management, strategic thinking? By $47 \%$ of respondents, their employers or they themselves as the management stress the volume and costs as the first ones, not quality. Product quality can be related to a high level of intellectual capital philosophy acceptance though. Tacit and explicit knowledge and work with it is an important part of intellectual capital and corporate education. The effort to transform tacit knowledge into explicit one (where possible) is in the questionnaire survey on a scale of 5 to 7 (rather maximum or maximum level) declared by $34 \%$ of respondents. It is important to realize that in certain contexts, tacit knowledge may include a larger portion of an organization's intellectual assets base [15]. Other questions in the questionnaire further prove that the presumed or declared status regarding 
intellectual capital, education, associated with the company development does not reach the level managers attribute to it.

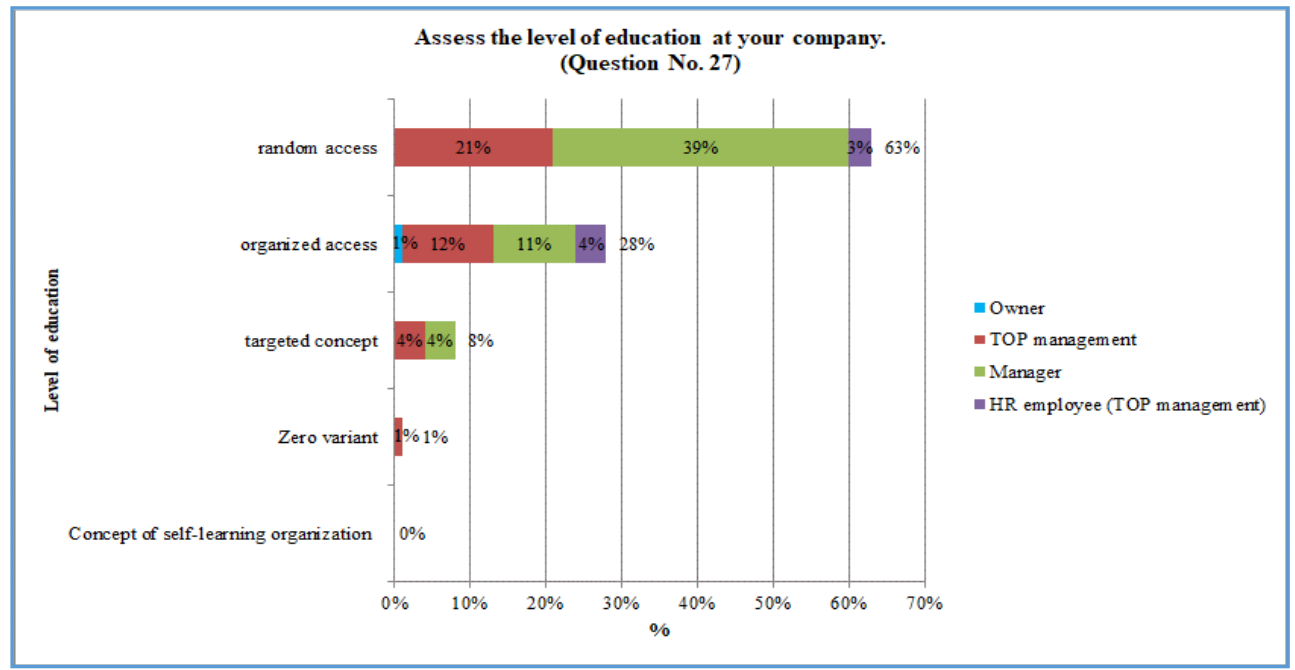

Figure 3. Assess the level of education at your company.

Source: own research (February - April 2018)

\section{Conclusions}

This paper brings a look at relations between intellectual capital, corporate education and company development in companies of the Czech Republic with up to 500 employees. The professional literature agrees on the importance of these topics and offers various types of researches and new stimuli that expand the boundaries of current knowledge. In the research, the authors addressed owners, shareholders, TOP management members, HR department members or another department, task of which the co-responsibility for recruiting new employees is, managers (participating in the selection of their subordinates) of companies with up to 500 employees throughout the Czech Republic. Data of 114 respondents were elaborated and worked with. The purpose of research was to find answers to the following research questions: 1 . Does the idea (principles) of intellectual capital affect the level of internal education? 2. Does the company intellectual capital influence the development of its business? 3. Does most management consider the level of corporate education an organized approach? The respondents' answers proved that knowing the idea (principles) of intellectual capital has fundamental impact on the internal education level. They also proved that intellectual capital influences business development. The third research question was answered negatively because organized approach towards education was chosen by only $28 \%$ of respondents. Other data and research results being presented by the authors show discrepancy between what managers declare and reality.

The questionnaire survey and semi-structured interviews, concerning companies with up to 500 employees, brought alarming findings in many respects. Confrontation of information and feedback for all involved and interested serves as the added value of the research and the obtained data. It is necessary to think about those data and work with them, share them with everybody who can change current situation. One of recommendations is to continue similar analyzes. Real knowledge of the situation in individual companies can present a high degree of added value for both the contracting authority and the evaluators. The results of the survey may encourage andragogy pedagogues and educational companies to increase their interest in these topics in order to 
improve awareness among students and staff. The formation of corporate intellectual capital is an important step in building an effective synergetic interaction of all points of the triangle made of "business-education-science". This triad is a key tool for the strategic development of the knowledge-based economy for any country in the world [16]. The level of intellectual capital exceeds the boundaries of the company. Companies report their intellectual capital to help stakeholders (e.g. shareholders, investors) understand the true value of the company (which includes intellectual capital values) [17]. This overlap is so important and so great for a company that managers have concluded that it is possible for companies to increase the value of their stock market capitalization by comprehensively reporting their intellectual capital [18]. Development of an intellectual capital philosophy in companies is of indisputable importance. Today, the concepts of dual learning, lifelong learning or retraining and qualifications are becoming an integral part of everyday operation [19]. In the age of the information society, rapidly and often unpredictably changing, creative and educated employees with quality human capital will be the most desirable goods. Every move forward and in a surprising direction will be a clear competitive advantage.

The paper was supported within the project of the Student Grant Competition at the Faculty of Economic VŠB-Technical University of Ostrava SP2020/33.

\section{References}

1. Mahmood, T., Mubarik, M.S. (2020). Balancing innovation and exploitation in the fourth industrial revolution: Role of inetellectual capital and technology absorptive capacity. Technological Forecasting and Social Change, 160, 1-9.

2. Low, J., Kalafut, P.C. (2002). Invisible Advantag. Cambridge: Perseus.

3. Kozera-Kowalska, M. (2020). Intellectual capital: ISVA, the alternative way of calculating creating value in agricultural entities-case of Poland. View Journal Impact, 12(7), 1-19.

4. An, M.H., Ri, G.Y., Rim, G.N. (2020). Intellectual product and method of assessing the competitiveness of an enterprise with it. Journal of the Knowledge Economy, 11(3), 1059-1085.

5. Barták, J. (2006). Skryté bohatstvi firmy. Praha: Alfa.

6. Edvinnson, L., Malone M.S. (2001). Kapitat intelektualny. Warszawa: Wydawnictwo Naukowe PWN.

7. Truneček, J. (2003). Znalostní podnik ve znalostní společnosti. Praha: Professional.

8. Barrena-Martinez, J., Cricelli, L., Ferrandiz, E., Greco, M., Grimaldi, M. (2020). Joint forces: Towards an integration of intellectual capital theory and the open innovation paradigm. Journal of Business Research, 112, 261-270.

9. Dearden, L., Read, H., Van Reenen, J. (2019, November 15). The Impact of Training on Productivity and Wages: Evidence from British Panel Data. http://cep.lse.ac.uk/pubs/download/dp0674.pdf

10. Konings, J., Vanormmelingen, S. (2019, November 17). The Impact of Training on Productivity and Wages: Firm-Level Evidence.

https://www.researchgate.net/publication/45143473_The_Impact_of_Training_on_Pro ductivity_and_Wages_Firm-Level_Evidence

11. Armstrong, M. (2007). Řizení lidských zdrojů. Praha: Grada. 
12. Saeidi, P., Saeidi, S.P., Guttierez, L., Streimikiene, D., Alrasheedi, M., Saeidi, S.P., Mardani, A. (2020, August 21). The influence of enterprise risk management on firm performance with the moderating effect of intellectual capital dimensions. https://www.tandfonline.com/doi/full/10.1080/1331677X.2020.1776140

13. Karasneh, A. (2020, September 1). Revitalizing the BSC through knowledge management: The mediating role of intellectual capital.

https://onlinelibrary.wiley.com/doi/abs/10.1002/pa.2359

14. Gashenko, I.V., Khakhonova, N.N., Orobinskaya, I.V., Zima, Y.S. (2020). Competition between human and artificial intellectual capital in production and distribution in Industry 4.0. Journal of Intellectual Capital, 21(4), 531-547.

15. Kianto, A., Ritala, P., Vanhala, M., Hussinki, H. (2020). Reflections on the criteria for the sound measurement of intellectual capital: A knowledge-based perspective. Critical Perspectives on Accounting, 70, 1-15.

16. Kalenyuk, I., Grishnova, O., Tsymbal, L., Djakona, A., Panchenko, E. (2020). Formation of intellectual corporate capital: methods and modern trends. Bulletin of the National Academy of Sciences of the Republic of Kazachstan, 1, 182-191.

17. Ousama, A.A., Al-Mutairi, M.T., Fatima, A.H. (2020). The relationship between intellectual capital information and firms' market value: a study from an emerging economy. Measuring Business Excellence, 24(1), 39-51.

18. Widiatmoko, J., Indarti, M.G.K., Pamungkas, I.D. (2020). Corporate governance on intellectual capital disclosure and market capitalization. Cogent Business \& Management, 7(1), 21-32.

19. Caganova, D., Hlasnikova, P.R., Vranakova, N. (2020). Intellectual capital as a key factor in the automotive Industry. Mobile Networks \& Applications, 24(6), 2024-2031. 